\title{
Suffering Our Way to Salvation: Ivone Gebara, Elisabeth Schüssler Fiorenza, and the Adequacy of the Cross as a Symbol for Women
}

\author{
Amy Chapman \\ Boston College School of Theology and Ministry
}

This article explores the theologies of the cross and salvation put forth by Brazilian liberation theologian Ivone Gebara and American theologian Elizabeth Schüssler Fiorenza. Both scholars depart from a traditional Anselmian theology of the cross and salvation, holding that for some women Anselm's understanding is insufficient. Both theologians claim that within Anselm's theology of the cross and salvation is the understanding that suffering is necessary for salvation. Wishing to dispute that, Gebara examines the lived experiences of women while Schüssler Fiorenza focuses on references from scripture. Both women arrive at the conclusion that the cross proves to be an inadequate symbol for salvation for some women, and Schüssler Fiorenza provides the empty tomb as an alternative symbol.

Amy Chapman serves as the Director of Faith Formation at St. Ignatius Church in Chestnut Hill,

Massachusetts. She holds an A.M. in Developmental Psychology and will graduate in May with a CAES degree in Religious Education. 


\section{Introduction}

The cross, objectively an instrument of torture and execution in the time before and after the life of Jesus of Nazareth, has become one of the dominant symbols of Christianity since Jesus' crucifixion nearly two thousand years ago. From the beginning, theologians have attempted to understand the meaning of Jesus' death on the cross and what that death means for those who believe he is the Christ. These theologians have ranged from the first followers of Jesus, who in the aftermath of the frightening and confusing execution of their friend needed to make sense of his death, to twenty-first century feminist theologians seeking to understand that same excruciating event in light of the lived experienced of oppressed people. These scholars and believers are seeking answers to the same question: what does the death of Jesus the Christ mean for humankind?

\section{Theologies of the Cross: The Tension Between Anselm and Feminist Theology}

An intimate connection between the event of the cross and the triumph of salvation has been assumed since the beginning of Christianity. Theologians have closely linked these two events, believing "that something good happened, namely the salvation of sinners, when or because Jesus was killed." How the death of Jesus Christ on the cross brought about salvation has been a recurrent topic of debate. Among those who have framed answers to this question, Anselm of Canterbury is a major figure. While the contributions of Anselm to the theology of the cross are undeniable, they are also controversial. ${ }^{2}$ Recently, feminist theologians have taken issue with Anselm's theology and the direction in which it has been developed. Providing an

\footnotetext{
${ }^{1}$ J. Denny Weaver, A Nonviolent Atonement (Grand Rapids, Michigan: William B. Eerdmans Publishing Company, 2001), 2.

${ }^{2}$ Flora A. Keshgegian, "The Scanal of the Cross: Revisiting Anselm and His Feminist Critics," Anglican Theological Review 83 (2000): 475.
} 
adequate, thorough treatment of Anselm's theology of atonement, as well as the feminist critique of that theology, is beyond the limits of this paper. Given these limits, this paper relies on the work of Flora Keshgegian in interpreting Anselm's theology. ${ }^{3}$

In Cur Deus Homo, which stands as his definitive work on the matter, Anselm presents his understanding of the meaning of Jesus' death and its implications for the salvation of humanity. Keshgegian's reading of Cur Deus Homo begins by asserting Anselm's claim that "human beings were created to be in a particular relationship with God and because of sin they are not capable of living as they ought and rendering to God what they owe." ${ }^{4}$ Because of this gap created by sin, human beings owed something to God that they could not pay; because they could not pay, they had to be punished. The punishment for these sins was death, and the only way in which humankind could escape that death was to satisfy God, but this was something that human beings could not accomplish on their own. God is certainly capable of paying the debt humans owe to God, but "Anselm argues...that this is not fitting for God." beings, "must endure punishment...[and] God's plan for creation remains disrupted." Anselm argued that the way to restore God's creation and prevent human beings from being punished was Jesus Christ. For Anselm, because Jesus is both human and divine, he is able to pay humanity's debt to God, but because he is sinless he also does not deserve to be punished. In

\footnotetext{
${ }^{3}$ See Flora A. Keshgegian, "The Scandal of the Cross: Revisiting Anselm and His Feminist Critics," Anglican Theological Review 83 (2000). In this article Keshgegian explores the tension between feminist theologies of the cross and the Anselmian theology of the cross. She first explicates the positions of a variety of feminist theologians and the critiques of Anselm. She then turns directly to Anselm's theology in the hope of determining whether the feminist critiques are valid. Her examination focuses on "reviewing Anselm's argument and setting it in the context of his time and of his social, religious and ecclesial setting," 480 .

${ }^{4}$ Ibid., 480.

${ }^{5}$ Ibid.

${ }^{6}$ Ibid.
} 
this way, Jesus' death "sets right the order of justice and accomplishes redemption for human beings."7 Put succinctly, Jesus died so that humans might live.

From this Anselmian understanding of the cross and salvation emerges "the central image of Christ on the cross as the savior of the world [which] communicates the message that suffering is redemptive." ${ }^{\prime}$ Though this is not the message all hear and see in the cross, for some an idea has developed that in order to be saved one must imitate Jesus' suffering on the cross. Suffering is then be perceived as good, necessary, and operative in human beings' attainment of salvation. Because Anselm's theory of atonement can be seen as promoting the idea that "redemption and salvation are wrought through sacrifice, submission, surrender, freely chosen suffering, scapegoating, and violence against the innocent," it has come under recent criticism. ${ }^{9}$

Modern scholars, and in particular feminist theologians, have "severely criticized the satisfaction theology of Anselm for its focus on suffering and the cross as satisfaction."10 In response to theologies of the cross which function to support the marginalization and victimization of people who already find themselves in those places, feminist theologians have been developing new understandings of the way in which the life, death, and resurrection of Jesus lead to salvation. These contemporary theologians have used as their starting point the lived experience of people who, like Jesus, have been minimized, violated, and silenced. They look at women who have been abused, who are victims of prostitution, whose voices are not heard because they live in male-dominated societies, who feel disenfranchised because of the

\footnotetext{
${ }^{7}$ See the works of Mary Daley, Elizabeth Johnson, Rosemary Radford Reuther, Elisabeth Schüssler Fiorenza, Joanne Carlson Brown, Rebecca Parker, among others; Keshgagian, The Scandal of the Cross, 481.

${ }^{8}$ Joanne Carlson Brown, Rebecca Parker, and Carol R. Bohn, Christianity, Patriarch, and Abuse: A Feminist Critique (New York: Pilgrim Press, 1989), 2.

${ }^{9}$ Elisabeth Schüssler Fiorenza, Jesus: Miriam's Child, Sophia's Prophet (New York: Continuum, 1994), 100.

${ }^{10}$ Ibid., 105.
} 
exclusive use of male-centered language. ${ }^{11}$ These theologians look at the lives of these women who, because of their lived experiences, do not see in the cross the joy, hope and promise of salvation but rather divinely-willed suffering, as well as a sanctioning of the systems which hold them in oppression. ${ }^{12}$ From this basis, these theologians are attempting to understand the cross and salvation in ways that honor the experience of those whose lives have been marginalized. Part of the work of these feminist theologians has also been to examine the ways in which Christianity has been used to maintain patriarchal and hierarchal systems with the hope of developing alternative understandings of the cross and salvation that are more life-giving and true to the experience of Jesus of those who have been hurt by such systems. Christian theologians have begun to examine the ways in which Christianity has been used to maintain patriarchal and hierarchal systems and are attempting to refocus the attention of the faith back to Christ who arguably sought to shatter those very systems. ${ }^{13}$

Recent research on the theology of the cross has challenged "the way that classic atonement images... have accommodated violence of the sword, slavery, racism... and violence against women." ${ }^{\prime 14}$ In particular, the qualities that Christianity idealizes, especially for women, are also those of the victim: sacrificial love, passive acceptance of suffering, humility, meekness, etc. Since these are the qualities idealized in Jesus "who died for our sins" his functioning as a model reinforces the scapegoat syndrome for women. ${ }^{15}$

\footnotetext{
${ }^{11}$ See Joanne Carlson Brown, Rebecca Parker, and Carol R. Bohn, Christianity, Patriarchy, and Abuse; Ivone Gebara, Out of the Depths: Women's Experience of Evil and Salvation, trans. Ann Patrick Ware (Minneapolis: Fortress Press, 2002); Elisabeth Schüssler Fiorenza, Jesus: Miriam's Child, Sophia's Prophet; Elizabeth Johnson, She Who Is: The Mystery of God in Feminist Theological Discourse (New York: The Crossroad Publishing Company, 1999).

${ }^{12}$ Gebara, Out of the Depths, 106-107.

${ }^{13}$ Schüssler Fiorenza, Jesus: Miriam's Child, Sophia's Prophet; Weaver, The Nonviolent Atonement.

${ }^{14}$ Weaver, The Nonviolent Atonement, 122.

${ }^{15}$ Mary Daly, Beyond God the Father (Boston: Beacon, 1973), 77.
} 
In other words, some of the ways in which the cross is theologized have justified and perpetuated the ways in which marginalized peoples suffer at the hands of oppressors. These theologies of the cross can be seen as condoning, if not advocating, suffering, oppression, and violence. It is in response to these negative interpretations of the cross that feminist theologians are writing, hoping to develop new ways of understanding the cross which integrate the life, death and resurrection of Jesus.

\section{Gebara's Theology of the Cross}

Among the theologians who have been doing this work, Ivone Gebara has lived and worked as a pastoral minister with women in both urban and rural Brazil that have suffered evils and has reimaged the cross and salvation in light of their experiences. Through this method, Gebara is able to examine women's lived experience of the cross and of salvation. From this starting point, Gebara insists that the Anselmian understanding of the death of Jesus not only fails to match the lived theology of the women with whom she works, but it actually perpetuates the evils which befall them. ${ }^{16}$ A close analysis of Gebara's theology provides a thoughtful understanding of why the classical conceptions of the cross and salvation do not work for some women and how both need to be reexamined in order to provide these women with an understanding of Jesus' death and resurrection which is life-giving rather than oppressive. When read in conjunction with other feminist theologians, Gebara's meaning-making becomes the lens through which alternative understandings of the cross and salvation can take be seen.

In examining the efficacy of the cross in terms of its functionality as a symbol of salvation for women, one must first take into account the fact that Jesus came in the form of a male. According to some, the sex of the historical Jesus seems to play a far greater role in the

\footnotetext{
${ }^{16}$ Gebara, Out of the Depths, 107.
} 
understanding of the ministry, death, and resurrection of Christ beyond other similar traits and qualities. ${ }^{17}$ Elizabeth Johnson argues that this is so because Jesus, as a male, was viewed by the early Christian church-being situated within the Greco-Roman sphere of influence-as a traditional, patriarchal head of household. The importance assigned to the sex of Jesus produced "the belief that a particular honor, dignity, and normativity accrues to the male sex because it was chosen by the Son of God himself for the enfleshment of the incarnation." 18 Because of the historical context of early Christianity, the fact that God came to earth as a man is seen to have led to a valuation of men over women, Jesus' sex “function[ing] as a sacred justification for male dominance and female subordination."19

Scholars have therefore asked if female salvation is even possible since Christ was male, and Gebara echoes their questions with her own: "Will women by reason of their sex be excluded from any capacity for salvation?"20 While the answer to this question is often no, Gebara argues that "this male-centered interpretation [of Jesus on the cross] eliminates the potential for the bodies of women to serve as symbols of salvation."21 From the onset, women are at a significant disadvantage in their participation in the cross and salvation, simply because Christ came to earth as a man.

The sex of Jesus is not the only aspect of the theology of the cross where one finds a chasm between the experience of men and women. Gebara understands "the cross as a concrete suffering, one that is physical, psychological, and social." ${ }^{22}$ Though the cross stands as a representation of suffering for all people, Gebara argues that people experience suffering

\footnotetext{
17 Johnson, She Who Is, 151-153.

${ }^{18}$ Ibid., 152.

${ }^{19}$ Ibid., 151.

${ }^{20}$ Rosemary Radfor Ruether, Sexism and God-Talk: Toward a Feminist Theology (Boston: Beacon, 1983); Gebara, Out of the Depths, 117.

${ }^{21}$ Gebara, Out of the Depths, 118.

${ }^{22}$ Ibid., 110.
} 
differently. These differences require people to acknowledge that what is true and meaningful for one group of people may have a very different meaning for another. Men and women suffer differently, and the weight of those differences greatly impacts the ways in which the cross as a symbol of salvation functions for each. ${ }^{23}$

From Gebara's perspective, “male suffering in the form of acts of public heroism has a redemptive role for the country, the nation, [and] the people," while female suffering "has no such role." 24 Gebara identifies male suffering as "public suffering in the name of a group," thus providing ways in which men's suffering ultimately brings them, and often others, beyond their suffering. ${ }^{25}$ For instance, it is often men who defend their countries in times of war. While those who do so undoubtedly suffer in the process, that suffering has intrinsic value, both to the individual and to the group. In contrast, the ways in which women suffer are quiet, unacknowledged, and offer no redemptive qualities. An example of this is forced prostitution, where women are hurt and no glimmer of salvation can be found. Beyond this, the suffering of men is seen as normative: how women suffer is less important because it does not measure up to the experience of male suffering. ${ }^{26}$ For those who view suffering as a necessary component of salvation, male suffering is seen as a vehicle for that salvation whereas female suffering functions merely as a vehicle for misery.

There is an additional layer of difference between men and women which some have suggested is critical to an understanding of the cross as salvific: women suffer in ways that men do not simply because they are women. ${ }^{27}$ In the world in which Gebara works, being born a

\footnotetext{
${ }^{23}$ Ibid., 111.

${ }^{24}$ Ibid.

${ }^{25}$ Ibid.

${ }^{26}$ Ibid.

${ }^{27}$ Ibid., 113.
} 
woman is seen as a "curse." 28 To be a woman is to suffer, and yet there is no expectation or even hope of salvation by virtue of the fact that one is a woman. In this way, too, female suffering functions very differently from male suffering: if the cross presents to some women a symbol for suffering but not salvation, it is much more likely they will find in it oppression, not salvation.

This is precisely the understanding of the cross that Gebara sees in the women with whom she works. For these women, "the symbol of the cross has evoked thoughts not always of salvation but rather of domination." ${ }^{29}$ Instead of a symbol of the way in which oppressive hierarchal structures are broken, Gebara argues that for the women with whom she has worked the cross has become a symbol of those oppressive structures. Traditional theologies of the cross claim that as Jesus was obedient to God, even unto death, and so people, especially women, must be obedient also. As Elisabeth Schüssler Fiorenza writes,

the notion that human sin can be atoned for only through the bloody sacrifice of G*d's own son serves to support the powerful in a society whose interests in domination and profit demand a multitude of human sacrifices. Most pernicious for women and subordinated men is the notion of redemption as freely chosen obedience and self-giving love. Such a theological belief also supports hierarchical relationships of domination. ${ }^{30}$ This understanding of the nature and function of Jesus' death on the cross creates an assumption that people choose obedience that requires submission to authority rather than liberation from oppression, and that that choice is both free and desired by God. While obedience to God is virtuous, people in power yoke this obedience to God with obedience to themselves or to social

\footnotetext{
${ }^{28}$ Ibid.

${ }^{29}$ Ibid., 112.

${ }^{30}$ Schüssler Fiorenza, Jesus: Miriam's Child, Sophia's Prophet, 101.
} 
structures. This is neither virtuous nor salvific, and it can lead to oppression. For example, men in positions of power have used "Jesus' suffering on the cross... as an excuse for justifying the misery imposed on the poor and especially on women."31 It is within this submission that "their sacrifice finds its value," much as Jesus' sacrifice on the cross was valued by God and humanity. ${ }^{32}$ This understanding of the cross illustrates that obedience to power can be seen as God's will and it is through obedience that one has the opportunity to receive salvation.

Because of the close associations between authority and God, the penalty for disobedience to power is seen as tantamount to disobeying God. In keeping with this understanding that sees the marginalized in the position of the suffering Jesus on the cross and those in power in the position of God, "disobedience is flouting the authority of God and [God's] representatives, and disobedience is subject to punishment." ${ }^{, 33}$ Disobedience to God is clearly not the path to salvation, and thus the only option available as a means of achieving salvation is obedience. Schüssler Fiorenza says that this obedience allows for the systems of suffering present in society:

If one extols the silent and freely chosen suffering of Christ, who was "obedient to death," (Phil. 2:8), as an example to be imitated by all those victimized by patriarchal oppression...one not only legitimizes but also enables acts of violence against women and children. ${ }^{34}$

Rather than inviting those marginalized to question their marginalization and fight for a better experience of life, the call to follow Jesus' obedience seems to require submission to human authority as a condition for salvation. When seen in this way, the cross functions not to liberate

\footnotetext{
${ }^{31}$ Gebara, Out of the Depths, 112-113.

32 Ibid., 113.

33 Ibid.

${ }^{34}$ Schüssler Fiorenza, Jesus: Miriam's Child, Sophia's Prophet, 106.
} 
people from oppressive relationships and social structures but helps to maintain those very structures and thus to keep those who are marginalized in submissive roles.

Gebara argues that all of these interpretations of the cross, which focus on men's experience and ignore women's, have the potential to do a great deal of damage to women. She believes that this "male-centered interpretation...runs the risk of indirectly cultivating in individuals and in institutions a certain taste for the cross, a kind of pleasure in suffering." ${ }^{35} \mathrm{~A}$ man can look to other men's examples of suffering that are seen as tied to salvation, but women do not have a hope of having the same view. When people look to these experiences of men without balancing them with the experiences of women, male experience becomes the norm by which women are measured and often seem to fall short. Women do not find salvation through their suffering, yet because of some of the ways in which the cross has been theologized, women are required through the predominant symbol of their faith to remain in the submissive roles which further their suffering rather than seek routes out of these roles. This understanding of the cross can then perpetuate theology-sanctioned violence, oppression, and suffering.

For all of these reasons, the theology of the cross as it is predominantly understood does not function as a salvific symbol for some women. Though Gebara believes that "to cling to the cross of Jesus as the major symbol of Christianity ultimately affirms the path of suffering and male martyrdom as the only way to salvation and to highlight injustice toward women and humanity," she does not take this to mean that the symbol of the cross should be eliminated from Christianity. ${ }^{36}$ Rather, she believes that one must find "a sense of solidarity, in the cross and

\footnotetext{
${ }^{35}$ Gebara, Out of the Depths, 118.

${ }^{36}$ Ibid.
} 
beyond it."37 Men and women who suffer, in all respects, must acknowledge that suffering, give voice to it, and help each other find ways out of it.

For Gebara, Christianity's focus on the cross “as a source of liberation seems to repeat the same vicious circle of oppression and opens no door to a broader horizon" because not all are able to see liberation and salvation through it. ${ }^{38}$ She argues that it is not the suffering of Jesus on the cross that is the key to salvation, but rather the larger scene and what comes afterwards. Gebara writes, precisely in this situation the symbol of the life of Jesus is the most telling for women. His cross does not stand alone; the surrounding community shouts "no" to this assassination, "no" to this crucifixion, "no" to the powers that kill. Women stand around his cross as his friends, caring for his lifeless body so that life will not be further violated. This gesture is rich and symbolic because it leads to life. There are followers, men and women, who declare by their solidarity that unjust death does not have the last word. ${ }^{39}$ The execution of Jesus occurred within a context of people looking for wholeness rather than suffering. This interpretation stands in marked contrast to themes of domination and power, finding pleasure in suffering, and suffering as a condition for salvation. Instead, it portrays the death of Jesus as a horrific event, one in which people did not rejoice and instead stood for life in solidarity with the one who suffered. Rather than seeking suffering and hoping therein to locate salvation, Gebara understands Jesus' execution as a call to "[denounce] every form of violence and every kind of attack on the dignity of women in any culture or institution." ${ }^{40}$ Jesus' cross does not mean that suffering and violence ought to be tolerated, emulated, or longed for; rather,

\footnotetext{
${ }^{37}$ Ibid.

${ }^{38}$ Ibid., 116.

${ }^{39}$ Ibid., 115.

${ }^{40}$ Ibid., 116.
} 
it means that those evils should be fought against at every possible level, in every possible way, by all people.

\section{Gebara's Theology of Salvation}

Salvation looks different given this reimaging of the cross. Jesus' sacrifice and suffering for us allows human beings to hope that, at the end of time, we will not die but will rise to live eternally with God. Within that understanding of salvation lies the hope that all which limits people in this life will somehow disappear in the next life. In the meantime, however, this hope of eternal salvation allows people in power to continue to oppress those who are marginalized because the dominant theological understanding of the cross is seen as promoting suffering above liberation. Insofar as Jesus' death on the cross does encourage people to believe that the "suffering that comes from injustice will lead us to redemption," the classical view does condone suffering, ranging from domestic abuse to genocide. ${ }^{41}$ This "promise of resurrection persuades us to endure pain, humiliation, and violation of our sacred rights to self-determination, wholeness, and freedom," because eventually we will be freed from all that limits or hurts us. ${ }^{42}$

For Gebara, the idea of eschatological salvation "is able not only to allay the fear of life and death but also to be taken over by the powerful, with a view to dampen any rush toward the liberation of the poor." ${ }^{\prime 3}$ If the only possible salvation is one that comes at the end of time, then it is pointless and unnecessary to look for forms of it in this life. This understanding supports those in power: people who believe that wholeness is something only attainable in the next life will not seek to change the modes of oppression that prevent them from achieving it in this life. It is in the interest of those in power to maintain the understanding of salvation as wholly otherworldly, that God's reign should not be sought in the present moment. Eschatological salvation

\footnotetext{
${ }^{41}$ Gebara, Out of the Depths, 107.

42 Carlson Brown, Parker and Bohn, Christianity, Patriarchy and Abuse, 2.

${ }^{43}$ Ibid., 122.
} 
should not be a tool used to maintain subjugating social structures but rather as a believed-in and lived-for experience of those who have been liberated.

Salvation is therefore experienced not only eschatologically but also in the present-not once but repeatedly. For Gebara, the question is "what salvation (or salvations) do women need? What do women actually experience as salvation?" and the answer is that women need to be heard, valued, and lifted out of oppression. ${ }^{44}$ From this perspective, she is able to claim that "salvation is what helps us live in the present moment, even when it feeds the dream of a greater happiness." healed, gestures of tenderness, the straightened posture of a stooped woman, hunger satisfied for the moment, the birth of a child, a good harvest."46 These signs of life, rather than suffering, promote wholeness, and as such "can be held up as symbols...of salvation."47

In this understanding, the path to salvation is not a life lived in endurance of many small deaths and evils so that at the end of time there may be some peace, but rather a series of daily choices that promote wholeness and life for ourselves and others. This does not eliminate eschatological salvation, for, as Gebara writes, "claiming the dailiness of salvation is not to deny the possibilities opened by a perspective on the beyond of history." 48 However, the fact that human beings will be with God at the end of all time should not prevent us from thinking that we can and should find God in this life. From this perspective, we are called to be seeking ways, as Jesus did, to be in solidarity with others and to promote their wellbeing as well as our own, to see God in each other and to promote within our social structures God's reign. It should add to, rather than detract from, our faith tradition "to see... a redemption in the here and now, a

\footnotetext{
${ }^{44}$ Ibid., 109.

${ }^{45}$ Ibid., 121

${ }^{46}$ Ibid., 115.

${ }^{47}$ Ibid.

${ }^{48}$ Ibid., 123.
} 
redemption that takes flesh now, even if for the moment this salvation is contained within the limits of our body, our heart, and our daily routine." 49

The salvation found in the present, life-giving, and life-sustaining moments recognizes the places where God works through and walks with us to bring wholeness to all. Daily and earthly salvation means that one is to be seen as created in the image and likeness of God, to be treated with dignity and without violence, and to find ultimate happiness through routes other than suffering. Finding these routes begins with earthly salvation-working for the reign of God as presented in the ministry of Jesus that is "quite simply the deep desire and the urgent necessity of having our individual and collective body more widely respected." ${ }^{, 50}$

\section{Reimagining the Symbol of Salvation}

For some, the symbol of the cross epitomizes violence, oppression, subjugation, and death, and in so doing promotes life which is full of guilt, submission, and evil. Because of this, the cross is an oppressive symbol for many; what Jesus called for is ill-represented by using the cross as the pinnacle of his life and work. Instead, Gebara claims that there needs to be an alternative understanding of salvation that is life-giving and promotes wholeness, well-being, equality, and love. For Gebara, this is the recognition that Jesus' death on the cross was not the end of the story but the beginning of the Resurrection, and therein lies the key to salvation: God walks with humankind in this life. ${ }^{51}$

An image of this salvation which aptly describes the ways in which women can and do experience salvation is Schüssler Fiorenza's description of the empty tomb following the Resurrection. ${ }^{52}$ Centering the image of salvation on the empty tomb rather than on the cross has

\footnotetext{
${ }^{49}$ Ibid.

${ }^{50}$ Ibid.

${ }^{51}$ Ibid., 131.

${ }^{52}$ Schüssler Fiorenza, Jesus: Miriam's Child, Sophia's Prophet, 123.
} 
three important meanings for women. First, instead of placing a high value on suffering following from an emphasis on the cross, shifting the focus results in "the vindication of unjust suffering and death." ${ }^{, 53}$ Jesus' suffering is not the end of the story, and the empty tomb invites us to see the same in our own. Secondly, "the proclamation of the empty tomb locates the Resurrected One on earth, in Galilee. Resurrection means that Jesus, the Living One, goes ahead of us." "54 The Gospel accounts of the disciples' discovery of the empty tomb and their nearly simultaneous meetings with the resurrected Jesus indicate that Jesus is still with us, albeit differently. The empty tomb, in contrast to the cross, boldly shows that "Jesus' struggle did not end with execution and death." 55 We find Jesus with us in this life, raised from the dead and walking among us, and we find salvation, there, as well. As Schüssler Fiorenza writes, "by privileging the empty tomb as the originating space for the proclamations that Jesus of Nazareth, the Crucified One, has been vindicated, the announcement of this 'resurrection reality' opens up a road ahead into the messianic future."

Finally, the use of the empty tomb as a symbol of salvation holds up women's agency as valuable in the on-going work of Jesus. In each of the Gospel accounts, the disciples' first interactions with the resurrected Jesus were facilitated by women. The empty tomb "celebrates women as faithful witnesses who do not relinquish their commitment and solidarity with those who fall victim in the struggle against dehumanizing powers." ${ }^{57}$ The symbol of the empty tomb functions to bring attention to women's agency in creating and maintaining their experiences of earthly salvation and in furthering the reign of God. Connecting the cross to salvation by means of the empty tomb

\footnotetext{
${ }^{53}$ Ibid., 123-124.

${ }^{54}$ Ibid., 123.

${ }^{55}$ Ibid., 125.

56 Ibid.

${ }^{57}$ Ibid., 125-126.
} 
allows us to reclaim this space of resurrection for women's meaning-making today in the face of dehumanization and oppression. Feminist Christological discourses can take seriously the spaces of the brutal victimization of women and other nonpersons and at the same time claim wo/men's agency in either collaborating with or transforming such spaces of death. ${ }^{58}$

In this way, the empty tomb is the symbol for which Gebara is searching: it promotes the life and resurrection of Jesus, rather than his suffering, as a condition for salvation, and in so doing calls people to choose life over suffering as well. Further, the empty tomb delegitimizes violence against women, and it reminds us that Jesus is present in our lived experience and that we can find salvation there as well as at the end of time.

Anselm of Canterbury sought to do this in developing his theology of the cross and salvation, providing a way for people to understand that Jesus' death was a sign of the depth of God's love for humanity and the way in which the break between human beings and God could be healed. While this theology of the cross has functioned well for many, for some it does not serve as a representative of either the reign of God or the meaning and experience of salvation. If that is true, then for those for whom the cross is limiting rather than liberating, a new theology must be developed.

Feminist theologians have begun this work, believing that the experience of women is not adequately addressed through this traditional theology of the cross. Those for whom the cross represents suffering rather than salvation need to be introduced to idea that God did not want Jesus to suffer, and similarly that God does not desire human suffering today. The hope for

\footnotetext{
${ }^{58}$ Ibid., 124-125.
} 
proposing alternative theologies of the cross and salvation is that through "feminist attention to the cross [one] can open one more door to the possible paths of salvation for our times."

This is not to deny that Jesus' death on the cross is tied to salvation but rather to claim that such a link does not make suffering the mechanism for salvation. If some people only see suffering in the cross, as Gebara and other feminist theologians claim that they do, then another way of understanding Jesus' life, death, and resurrection should be offered. Jesus' empty tomb provides this additional symbol of salvation. Through it, people are offered an opportunity to see salvation not only as the end of suffering but as the beginning of new life with God.

${ }^{59}$ Ibid., 112. 